\title{
Favourable Prototypes in the Ordering System at Coffee Houses in South India - A Customer Retention Strategy
}

\author{
Dr. Vazeerjan Begum \\ School of Business, Dept. of Management, American University of Ras Al Khaimah \\ PO Box 10021, Ras Al Khaimah, United Arab Emirates \\ Tel: 971-7-221-0900-1163Ｅ-mail: vazeerjan.begum@aurak.ae
}

Received: September 13, 2014 Accepted: December 4, 2014 Published: February 1, 2015

doi:10.5296/jmr.v7i2.6937

URL: http://dx.doi.org/10.5296/jmr.v7i2.6937

\begin{abstract}
In the dynamic business arena of today, companies are majorly customer-driven. To gain a competitive edge over the other competitors, a company has to provide its customers a value added service and products. This study has been conducted with the objective of identifying the need to implement a customer friendly and satisfactory ordering system at Coffee Joints in South India. The study has highlighted the emerging epitomes in the ordering system, which would help the customer by reducing waiting time, and thereby increases customer satisfaction and retention. The study has shown that respondents have shown a favourable attitude towards the use of the a mobile phone / Personal Digital Assistant (PDA), prepaid card and would like to have the additional facility of having a touch screen in order to reduce time and effort in placing their order.
\end{abstract}

Keywords: Customer Retention, Strategic Management, Growth Strategy, South Indian Coffee industry, New Prototypes 


\section{Introduction}

Customer retention can be viewed as a competitive advantageous strategy where customers are kept at total comfort that they do not think of switching to other competitive companies. It aids the business to build a strong forte against the competitors based on repeat sales, existing customers and positive word - of - mouth recommendations from loyal customers.

Customer retention is need of the hour strategy in the highly competitive global business world. It's a proven truth that majority of the company's market share is gained through the existing loyal customers. This truth opens up my mind to think the need for unwanted time and resources spent on convincing and capturing new customers.

Companies can effectively increase their level of profits to a large extent by retaining more of their existing customers. The nucleus notion is the triumph of any business depends majorly on maintaining smooth and deeper customer relationships, the business value need to be customer-oriented.

Customer Relationship Marketing is a view of customer retention. The main focal point of customer relationship marketing is to maintain and improve the rapport with the existing customers rather than fritter the valuable resources on reaching out for new customers. It is a technique of employing effectively the marketing communicational tools to create a unique and mutual long lasting relationship between the company and its valuable customers.

The companies need to be proactive to retain their customers to themselves. Otherwise, the churning of customers would start. The best way to monitor and control the churning of customers is to listen, react and give a positive feedback to the customers. Also the companies should create high level loyalty bondage with its existing customers by providing social benefits, confidence benefits and special treatments.

An effective complaint handling and customer recovery process in place would majorly benefit the business to focus its existing customers, furnishing them the value they expect from the company. Also a continuous communication with the customers through mails and call centers makes them feel at comfort and satisfies their ego needs.

\section{Coffee Joints development in India}

Coffee joints have burgeoned across India, making coffee an integral part of societal gathering places. In majority of the cosmopolitan cities in India, coffee joints have introduced a lot of uniqueness to have a competitive edge against their competitors. Some coffee joints provide free tablets/ ipads to surf, free wi-fi spots, business lounges to discuss business in informal environment, and even matchmaking services. There is an extensive assortment of coffee offerings, from size, flavour, preparation and toppings. Also ample number of specialty coffee joints very often to satisfy the growing needs of the customers.

\section{Coffee Joints in South India}

\subsection{Café Coffee Day}

Cafe Coffee Day is India's pioneers of the Café Concept. Its India's largest coffee 
conglomerate, Amalgamated Bean Coffee Trading Company Limited (ABCTCL). Café Coffee Day, started its first Café in 1996 at Brigade Road, Bangalore. It currently owns and operates more than 1500 cafes spread across 200 cities/towns across India. Café Coffee Day this year was bestowed with the prestigious ISO 22000:2005 certification by the internationally acclaimed DNV Business Assurance Food Safety System for its Food Safety management systems in its cafes.

\subsection{Starbucks}

In 2012 Starbucks announced a equal sharing joint venture with Tata Global Beverages, called Tata Starbucks Ltd., which would own and operate outlets branded "Starbucks, A Tata Alliance". On 19 October 2012, Starbucks opened its first store in India, at Mumbai. Currently, Starbucks operates 60 outlets in 7 cities of India.

\subsection{Java Green}

Javagreen is present in over 100 cities within India with a mix of store in store formats and independent outlets. They are currently open at Reliance Web Worlds in the cities of Chennai, Kochi, Bangalore, Hyderabad, Ahmedabad, Pune, Mumbai, New Delhi \& Kolkata.

\subsection{The Barista}

Barista Coffee Company, a wholly-owned subsidiary of Sterling Infotech Group, is changing its positioning from a premium retail coffee outlet to that of an eating joints, which will be serving pre-cooked quick-bites along with other beverages. Currently, Barista in India has over 130 Barista Espresso Bars and Corners.

\subsection{Qwiky's Coffee Pub}

Qwiky's is considered as a heaven where guests can sit back, relax, reconnect with neighbors and make new friends while enjoying specialty coffees and other simple leisure's of life in a friendly low-key environment.

\section{Significance of Coffee Joints}

Until the early 1990s none never really would have heard of Coffee Joints. Now the times have changed. Today, many coffee house visitors come alone to read or with a small group of friends for intellectual conversation. They walk up to a counter, pay for their beverage and find a nice quiet corner to settle into. Huge contract, business proposals are signed at Coffee houses. Home makers relax with their friends and family at coffee pubs. Students from the universities also frequented coffee houses, often spending more time at the shops then at school. Now-a-days, even marriage proposals are made at Coffee houses.

\section{Ordering System in vogue}

The current ordering system followed by the majority of the Coffee Joints in South India is personal order taking method through waiters. 


\section{Proposed Ordering System intended to be introduced}

The study intends to implement the following modes of ordering system in the Coffee Joints in order to enhance their customer service.

The proposed modes of ordering system to be implemented are; Mobile Phone or Personal Digital Assistant, Coffee Joint Prepaid Card and Touch Screen System.

\section{Objectives of the study}

This study titled "Favourable prototypes in the ordering system at Coffee Houses in South India - A Customer Retention Strategy" has the following objectives:

\subsection{Primary Objective}

To identify the need to implement a new ordering system with reference to Coffee Houses in South India.

\subsection{Secondary Objectives}

To identify the levels of satisfaction with respect to the existing ordering system in the Coffee Joints.

To analyze the factors influencing the choice of a particular Coffee Joint.

To analyse the type of problem/s faced by the respondents at the coffee joints.

\section{Research Methodology}

The research design adopted for the study has been descriptive and conclusive research. The main tool used to collect primary data has been a well-structured-undisguised questionnaire. Secondary data has been collected from sources such as: Books, Magazines, Journals, Newspapers, and Websites. The sampling technique adopted for the present study has been non-probability sampling.

The study covered 2500 individuals confined to different coffee joints customers of, Coffee Day, Starbucks, Barista, Nescafe, Java green, operating in South India (Chennai, Bangalore, Hyderabad \& Cochin). The respondents included both men \& women.

The various statistical tools that were used for the analysis of the collected data are as follows: Percentage Method, Weighted Mean Ranking Method, Chi - square Test, Analysis of Variance and Kendall's Coefficient of Concordance.

\section{Findings}

The study has highlighted the need to implement a new ordering system at Coffee Joints in South India on account of the long wait required by the customers due to the heavy rush during peak hours.

Today in the light of the extensive use of mobiles and PDA, the need for implementing a new ordering system is felt. Also it is hoped that the study would help customers to save on time and effort, thereby lead to higher customer satisfaction and retention. 
$20 \%$ of the respondents faced problems at the coffee joints out of which $8 \%$ of the respondents said that the most important problem faced is the lack of seat or table. This was followed by the problems delay in order taking (6\%) and delay in serving an order (4\%).

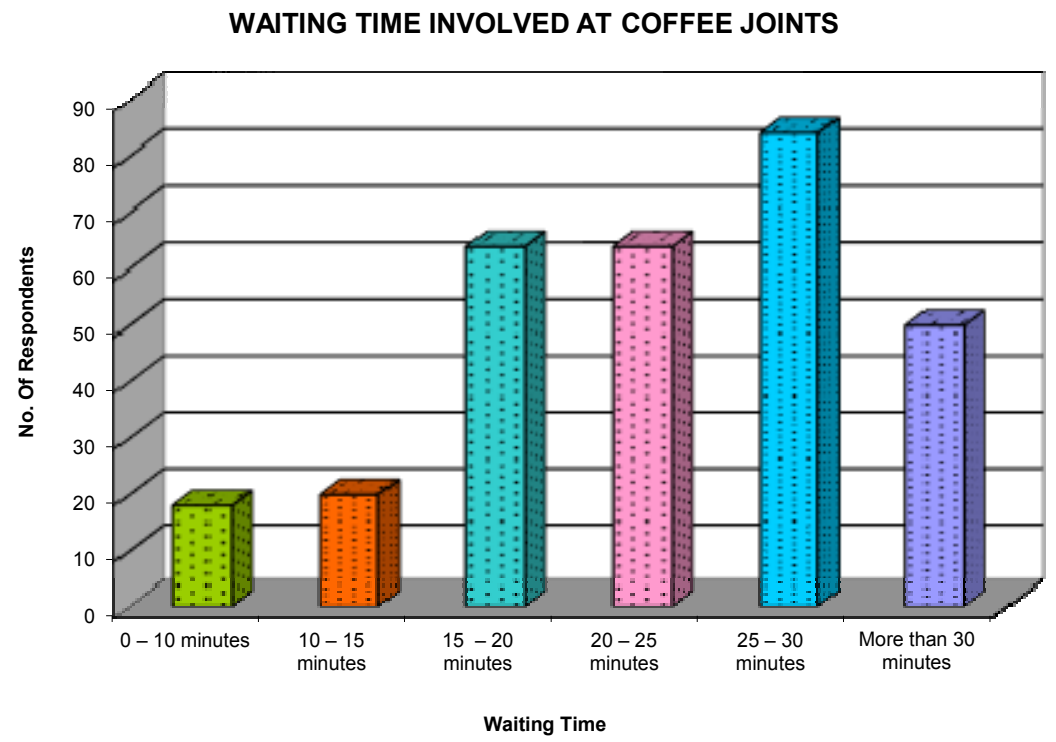

Figure 1. Waiting time involved at Coffee Joints.

$49 \%$ of the respondents say that the wait for about $20-30$ minutes. However, $17 \%$ of the respondents were forced to wait more than 30 minutes. Very few (6\%) said that it takes just less than ten minutes for them to be served their orders.

Greater parts $(60 \%)$ of the respondents were not quite satisfied with the current ordering system. Also majority $(90 \%)$ of the respondents were interested in the desire for a change in the existing ordering system.

The best part (90\%) of the respondents said that they will regularly use mobile phone/ PDA, Coffee Joint Prepaid Card and the Touch Screen System for ordering at coffee joints and only a very few said that they would never use the same.

Major portions $(90 \%)$ of the respondents feel that they would naturally attach importance to the type of touch screen. The preference to have a simple system would prove to be user friendliness.

Majority (90\%) of the respondents are highly willing to visit the coffee joints if the touch screen system of ordering is introduced and only a very meager percentage of the respondents are not interested in the same.

The ranking of the factors influencing choice of a particular Coffee Joint are as follows: Quantity was the most important service factor which influenced the favourite coffee joint followed by price, ambience, customer care, varieties of offer, strategic locations and car parking facilities. 


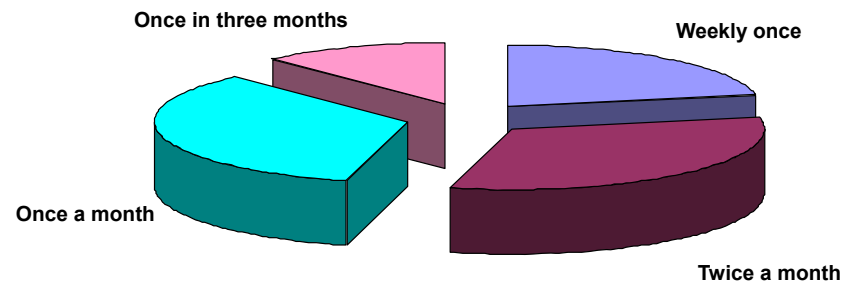

Figure 2. Respondents' frequency of visit to coffee joints

$34 \%$ of the respondents visit coffee joints once in a month, $32 \%$ of the respondents visit the coffee joints twice a month, $22 \%$ of the respondents visit the coffee joints once a week, and $12 \%$ of the respondents visit the coffee joints only once in three months.

FACTORS AFFECTING CHOICE OF COFFEE JOINTS

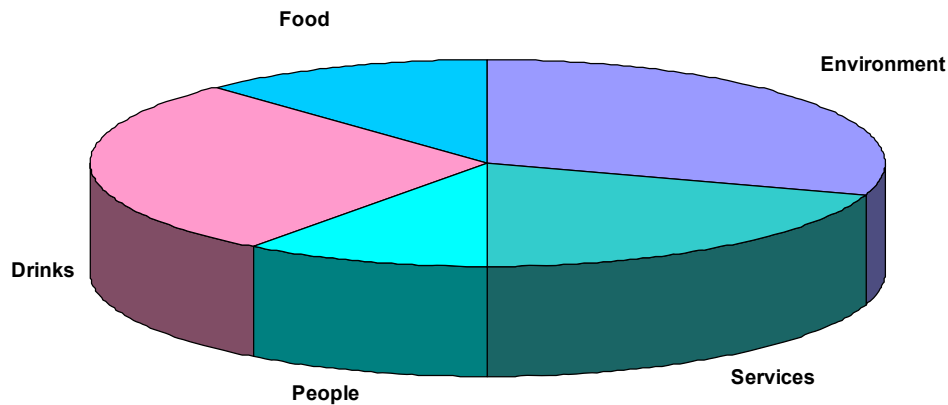

Figure 3. Factors affecting the choice of the coffee joints

$30 \%$ of the respondents felt that environment is the most important factor affecting choice of a particular coffee joint. Respondents are giving secondary importance to the products and services offered by the various coffee joints. Equal amount of importance is being given to the food and the people serving the food in the joints. Hence, the company has to concentrate on training their employees to be a customer friendly employee and equip them with all adequate etiquettes.

\section{Recommendations}

The following suggestions would help Coffee Joints not only to retain their existing customer 
(which is considered to be more difficult than attracting new customers) but also increase their customer list.

The coffee joints should provide more seating space. More tables and chairs need to be provided. Perhaps table and chairs that occupy less space could be replaced in place of the existing ones so that seating capacity remains the same. This suggestion is put forth assuming that space is a constraint for the Coffee Joints.

Since Coffee Joints have to be strategically located, invariably parking becomes a problem. This is another aspect, which the Coffee Joints have to bear in mind. Perhaps nearby vacant plots could be hired so as to encourage customers to come in big lots. If parking is not a constraint, then customers might come as a family in cars.

Since there are huge delays in the ordering system both with respect to taking of an order and serving of an order in Coffee Joints, the new ordering system could be introduced keeping in mind the preference of the respondents as indicated by the study.

Initially to encourage people to use the new system, some gifts and prizes could be introduced. This would act as a big motivating factor in bringing in crowds of customers. This would also provide help to customers to acquaint themselves to the mew system and thus overcome the resistance to change.

Perhaps just before the introduction of the new ordering system, the details could be sent to all mobile owners. The list could be obtained from a service provider of airtime. This would help educate a large group of prospective customers. Attractive introductory offers would not only help to bring in new customers but would also help in capturing lost customers.

There are a few untapped market segments prevailing in the market, the coffee joints need to frame an effective market penetration strategy and capture all the untapped segments of the market.

Coffee joints can start developing some customer loyalty programme to its existing customers. This with retain the current customers and also help in converting the other infrequent customers into frequent customers.

It can enter into the supermarket arena and start diversifying the business. The coffee joints can extend their service to ice cream, wholesale food service, music compilations, and office coffee program. It can design its web site to sell supplies and educate consumers about coffee quality

\section{Conclusion}

The success or failure of a business such as Coffee Joint simply depends on the behaviour of customer company overtime. Customers begin a relationship with businesses and overtime, either decide to continue this relationship, or end it. At any point in this Life Cycle, the customer is either becoming more or less likely to continue doing business with you, and demonstrates this likelihood through their interactions with the service provider or seller. Hence it is imperative that every type of business pays more attention on retaining customers 


\section{Macrothink}

Journal of Management Research

ISSN 1941-899X 2015, Vol. 7, No. 2

than in going in search of new ones. Customers' satisfaction would lead to retention, which automatically would bring in new customers.

\section{References}

Berry, Leonard. (1983). Relationship Marketing. American Marketing Association, Chicago, 146. ISBN 0877571619

Buchanan, R., \& Gilles, C. (1990). Value managed relationship: The key to customer retention and profitability. European Management Journal, 8(4). http://dx.doi.org/10.1016/0263-2373(90)90115-M

Carrol, P., \& Reichheld, F. (1992). The fallacy of customer retention. Journal of Retail Banking, 13(4).

Gordon, Ian. (1999). Relationship Marketing: New Strategies, Techniques and Technologies to Win the Customers You Want and Keep Them Forever. John Wiley and Sons Publishers, 336. ISBN 0471641731

Jackson, Barbara. (1985). Build customer relationships that last. Harvard Business Review, 195. ISBN 0669111465

Reichheld, F., \& Sasser, W. (1990). Zero defects: quality comes to services. Harvard Business Review, Sept-Oct, 105-111

Café Coffee day About us. (2014). Retrieved from http://www.cafecoffeeday.com/aboutus

\section{Copyright Disclaimer}

Copyright for this article is retained by the author(s), with first publication rights granted to the journal.

This is an open-access article distributed under the terms and conditions of the Creative Commons Attribution license (http://creativecommons.org/licenses/by/3.0/). 